6. Михальченко М. Політична реальність в Україні: трансформація, модернізація, революція? / М. Михальченко // Сучасна українська політика. Політики і політологи про неї. - К., 2005. - Вип. 7. C. $18-27$.

7. Нова українська школа: порадник для вчителя : навчально-методичні матеріали / за заг. ред. Н. М. Бібік - Київ : ВД «Плеяди», 2017. - 206 c. URL: http://nus.org. ua/wp-content/uploads/2017/11/NUSH-poradnyk-dlyavchytelya.pdf (дата звернення: 10.04.2019).

8. Нові професійні ролі і завдання сучасного вчителя в контексті концепції Нової української школи // Всеосвіта : проект. URL: https://vseosvita.ua/library/ novi-profesijni-roli-i-zavdanna-sucasnogo-vcitela-vkonteksti-koncepcii-novoi-ukrainskoi-skoli-87162.html (дата звернення: 24.03.2019).

9. Скрипник М. Модернізація вітчизняної освіти XXI століття: проблема суб'єктності / М. Скрипник // Методист. - 2018. URL: http://lib.iitta.gov.ua/id/ eprint/709944 (дата звернення: 10.04.2019).

10. Скрипник М. Про мовну тенденцію в модернізації вітчизняної освіти: гра словами чи словесна гра. URL: https://ru.padlet.com/marina_scripnik/ csnocrxeqm7r (дата звернення: 10.04.2019).

Дата надходження до редакиії: 10.09.2019 р.
УДК 373.542

DOI: 10.37026/2520-6427-2019-100-4-100-103
Ірина ОЗАРЧУК,

асистентка кафедри іноземних мов

Національного університету водного господарства та природокористування, м. Рівне

\title{
ОСОБЛИВОСТІ ЗДОБУТТЯ ІНШОМОВНОÏ ОСВІТИ В ЗАКЛАДАХ ВИЩОЇ ОСВІТИ КРАЇН БАЛТІЇ
}

У статті розкрито особливості здобуття іншомовної освіти в закладах вищзої освіти країн Балтії, зокрема Естонії, Литві, Латвї. Окреслено розвиток іншомовної освіти в иих краӥнах під впливом сучасних інтеграиійних та глобалізаційних прочессів.

Ключові слова: іншомовна освіта, заклади вищоі освіти, іноземна мова, професійна іншомовна освіта, багатомовність.

В статье раскрыты особенности получения иноязычного образования в учреждениях высшего образования стран Балтии, в частности Эстонии, Литве, Латвии. Определено развитие иноязычного образования в этих странах под влиянием современных интеграционных и глобализационных процессов.

Ключевые слова: иноязычное образование, высшие учебные заведения, иностранный язык, профессиональное иноязычное образование, многоязычие.

The article is devoted to the theoretical coverage of the methodological tendencies of the development of higher education. The influence of globalization and internationalization of society on the development of higher foreign education is analyzed. The cognitive, developmental and educational aspects of foreign education in higher schools are characterized.

The article analyzes the development of modern high education in Baltic countries under the influence of the integration and global processes of the late XX th to the beginning of the XXI century. The theoretical approaches to the formation of content of foreign language education in Estonia, Lithuania and Latvia are analyzed. The role of foreign language education at the present stage of functioning of higher education in Baltic countries is revealed. The focus is on the educational objectives of the role of motivation and the need to study and possess more than one foreign language by students is highlighted.

It is proved that the Baltic countries laws contribute to plurilingualism, since the citizens of Estonia, Lithuania and Latvia are multilingual - two thirds of the population are able to speak at least two foreign languages, which is several times higher than the average of the European Union.

The article states that the Baltic countries are guided by the European Recommendations on Language Education: studying, teaching, evaluating the principles outlined in this document and the levels of language proficiency defined by the Council of Europe. The Estonian Lithuanian and Latvian foreign language strategy aims to promote the continuity of teaching and learning foreign languages, as well as the definition and assessment of language skills. Among the many strategic goals, the above issues are priorities in higher education.

Key words: foreign language education, higher education institutions, language, professional foreign language education, multilingualism. 
Постановка проблеми. Кінець XX - початок XXI століть характеризується стрімким зростанням кількості країн (із 27 до 47), що входять до Свропейського Союзу. Незважаючи на те, що вони мають різний ступінь соціально-економічного розвитку, сформованості демократичних прав і свобод, кожна iз них демонструє прагнення до міжнаціональної й міжкультурної взаємодії, а також багатомовного спілкування, яке, як відомо, дозволяе будь-кому вільно проживати у багатонаціональній Свропі.

Освіта та освітній процес - невід'ємна складова будь-якого суспільства чи держави загалом та окремо взятої особистості зокрема; це ніщо інше, як «невід'ємний супутник людства», який спонукає до еволюційного розвитку, технічного прогресу, підкорення нових світових вершин.

Одним 3 актуальних питань освітньої сфери сьогодення $є$ іншомовна освіта. Зокрема, саме 3 нею пов'язують успішну життедіяльність особистості у європейському полікультурному i мультилінгвальному суспільстві, вважають засобом формування потреби особистості бути соціально-мобільною, вільно почуватися в інформаційному та комунікаційному просторі [6, с. 237].

Ураховуючи вищезазначене, можемо стверджувати, що суспільною необхідністю для країн Свропи $є$ сьогодні створення ефективної системи іншомовної освіти, що передбачає реформування й оновлення традиційної системи та іiі підходів до навчання на всіх рівнях. Країни Балтії, зокрема Естонія, Литва, Латвія, не є винятком, адже швидко й продуктивно рухаються в обраному напрямі.

Аналіз наукових досліджень і публікацій. Питанням реформування вищої школи, впровадження інновацій в іншомовну підготовку студентів закладів вищої освіти країн Європейського Союзу, зокрема й Балтії, присвячено роботи низки вітчизняних (К. Балабанов [1], М. Кушнарьовата О. Грищенко [2], О. Першукова [3], С. Сисоєва та Т. Кристопчук [4], М. Тадеєва [6], Ю. Талалай [7] та ін.) і зарубіжних (Бра Бейлі, Мартін Хоуп [7] та ін.) науковців.

Порівняльно-педагогічні дослідження в цьому напрямі проводили М. Свтух, О. Матвієнко, А. Максименко, В. Кемінь, С. Гончаренко, В. Безпалько, I. Малафіїк, Т. Десятов та ін.

Аналіз досягнень сучасної вітчизняної та зарубіжної педагогіки, філософських, лінгво-психологічних, культурологічних та методичних аспектів розвитку сучасної іншомовної освіти в закладах вищої освіти (далі - 3ВO) країн Балтії дає підстави стверджувати, що цілісного історико-педагогічного дослідження, в якому було б представлено загальнонаціональні особливості іншомовної вищої освіти означених країн, на сьогодні немає, що й спонукало нас до написання означеної статті.

Мета статті - охарактеризувати основні напрями розвитку сучасної іншомовної освіти, а також особливості їі здобуття в закладах вищої освіти країн Балтії, зокрема в Естонії, Литві, Латвії.

Виклад основного матеріалу. Як відомо, мешканці країнах Балтії можуть сьогодні вільно переміщатися просторами Свропейського Союзу. Естонці, литовці, латвійці вільно мігрують Європою у пошуках роботи, кращого життя або ж з метою здобуття освіти. У зв'язку з цим виникає запитання: «Як їм це вдається?». Відповідь проста - інтеграція іншомовної освіти на всіх рівнях дозволяє долати мовні бар'єри, які зазвичай $є$ основною причиною непорозуміння людей.
Саме іншомовна освіта, яка в цих країнах відзначається високим рівнем розвитку та інтеграцією в усі сфери життя, дає можливість випускникам естонських, литовських та латвійських вишів не лише вільно спілкуватися, а й працювати відповідно до профілю в інших країнах, демонструючи при цьому неабиякий професіоналізм. Навчальні програми у ЗВО цих країн створені таким чином, щоб задовольнити потреби у підготовці висококваліфікованого фахівця, який вільно володіє кількома мовами у вузькоспецифічному напрямі.

Розглянемо особливості іншомовної вищої освіти у країнах Балтії більш детальніше.

Eстонія - невелика держава, розташована на Півночі Європи, що входить до складу країн СС. Із часу становлення Естонської Республіки мовне питання в країні було одним із найскладніших і найболючіших. Спочатку (до 1800 р.) державною мовою була німецька, а після входження Естонії до складу Російської імперії - російська. У 1920 р. державною мовою стала естонська [8, с. 98].

Особливістю навчання у ЗВО Естонії є те, що питання мовної політики будь-якого вишу вирішується на рівні Міністерства освіти і науки. Враховуючи той момент, що до початку навчання у закладі вищої освіти школярі вивчають три іноземних мови (перша - починаючи з третього класу, друга - в середніх класах, третя - в 10 класі), питання іншомовної освіти вирішується дещо нетрадиційно для нас. Для професійної та вищої освіти основною мовою навчання $€$ естонська, однак є окремі групи здобувачів освіти, які можуть навчатися російською або англійською мовами. Такий підхід до навчання можливий у зв'язку з тим, що в шкільній освіті найбільш популярною, тобто першою іноземною, є саме англійська мова, другою російська, а третьою - німецька і французька. Однак, навіть якщо учні вивчають англійську чи російську мови, обов'язковою все ж залишається естонська, на вивчення якої відводиться найбільша кількість годин, що визначається навчальними програмами.

Якщо ж студент навчається естонською, то питання іншомовної освіти набуває для нього нового спрямування, що вирішується радою університету. Як правило, вивчається основний курс іноземної мови, мета якого - вдосконалення навичок читання, говоріння, письма, а також освоюється курс професійної іноземної мови. Студенти не просто вчаться розмовляти англійською, російською, німецькою, французькою, італійською, шведською, фінською мовами, а й паралельно іноземною мовою викладаються профільні дисципліни.

При цьому роботу з розвитку професійних стандартів та необхідний рівень володіння естонською й іноземними мовами для опанування певної професії координує Естонський орган кваліфікації.

Закінчуючи навчальний курс, студенти складають іспит на знання іноземної мови на трьох рівнях: початковому (загальному), професійному, вузькоспецифічному. Таким чином, освітня політика держави спрямована передусім на те, щоб готувати фахівців, які вільно володітимуть кількома мовами (як на рівні користувача, так і на рівні професіонала), а в майбутньому зможуть переміщатися країнами СС, не відчуваючи при цьому мовного дискомфорту.

Крім того, за бажанням здобувачів освіти, мовна політика Естонії на високому рівні забезпечує знання не однієї, а кількох іноземних мов. Якщо студент виявляє бажання, він може освоювати одночасно дві чи навіть три іноземні мови. 
Для цього впроваджуються факультативні курси, навчання за індивідуальним графіком тощо [5, с. 3].

Нині Державний освітній стандарт вищої освіти Естонської Республіки спрямований на те, щоб заохочувати студентів до вивчення більше ніж однієі іноземної мови. 3 цією метою для підтримки освітніх стратегій на телебаченні використовують субтитрування програм, фільмів, що сприяє вивченню іноземних мов 3 дитинства, однак досягти вільного професійного спілкування іноземною мовою можливо лише, навчаючись у ЗВО.

Латвія - центральна із Прибалтійських країн, населення якої складає всього 2 млн жителів. Oсобливістю країни $є$ те, що майже чверть іiї населення має російське коріння, а як наслідок - більшість людей вільно володіє трьома мовами: латиською, англійською, російською.

Іншомовна освіта в країні впроваджується на всіх етапах навчальної діяльності, однак саме у закладах вищої освіти вона набуває нового, яскравого забарвлення. На відміну від Естонії, в Латвії питання пріоритетності мови поставлено не так гостро. Це передусім зумовлено тим, що, починаючи ще 3 дитячого садка, всі латвійці вивчають як мінімум дві мови. При цьому у ЗВО студенти мають можливість самостійно обирати мови, які є для них пріоритетними та вивчати їх упродовж усього періоду навчання [4].

У більшості закладів вищої освіти Латвії навчання здійснюється латиською мовою, однак якщо студент нею не володіє, це не є великою проблемою. На першому курсі студентам для вивчення пропонується латиська, російська чи англійська мови (на вибір). Однак варто пам'ятати: якщо студент прибув на навчання до Латвії з іншої країни, це не $є$ приводом для навчання тією мовою, яка йому зручна. Тобто, він зобов'язаний за 2-4 навчальних семестри освоїти латиську мову, відвідуючи навчальні факультативні курси, адже 3 кожним навчальним семестром проходить поступова інтеграція і перехід до державної мови навчання. Так, на першому курсі дозволяється навчання російською або англійською, на другому додаються курси, викладання яких здійснюється виключно латиською, і з кожним семестром їх стає все більше. Якщо студент має латиське коріння і навчається латиською мовою, здобуття іншомовної освіти проходить за дещо іншим спрямуванням.

Таким чином, пріоритетною для вивчення в країні $є$ англійська мова, на другому місці - російська, на третьому - фінська. Починаючи із дитячого садка, в дітей формують навички усного іноземного мовлення. У ЗВО іноземною мовою передбачено вивчення окремих курсів, тобто студенти складають іспити тією мовою, якою здійснюється навчання з даної дисципліни [9].

Для підготовки висококваліфікованих фахівців вузького профілю (саме на це спрямована вища освіта в Латвії) на останніх курсах навчання передбачено викладання дисциплін профільного рівня (фізика, хімія тощо) кількома мовами одночасно, наприклад, англійською, латиською, російською. За бажанням, можна також обрати французьку, італійську, фінську та інші мови.

Такий підхід до іншомовної освіти дозволяє випускникам латвійських $3 \mathrm{BO}$ вільно переміщатися територією Європи, працювати практично у будь-якій країні, враховуючи свій профіль [3, с. 92].
Литва - третя країна, що входить до складу країн Балтії. Вона розташована на перетині Східної та Західної Свропи. Враховуючи історичне минуле й особливості географічного розташування, корінні мешканці Литви вільно володіють кількома мовами, як на рівні говоріння, так і письма.

Програми вивчення іноземних мов визначаються Міністерством освіти і науки Литви на всіх іiі рівнях. Як правило, першою іноземною мовою є російська - саме їі вивчають діти в дитячих садках, а також у молодшій, середній та старшій ланках школи.

Особливістю вищої освіти у Литві є те, що на початку навчання студентам, як правило, пропонують перелік іноземних мов, однак, що важливо, кожен заклад має право вибору однієї обов'язкової іноземної мови, яку будуть вивчати всі без винятку студенти. Так, у Вільнюському університеті обов'язковою дисципліною для всіх студентів філологічного факультету є латина. Крім того, серед студентів-філологів усе більшої популярності набувають подвійні профілі, наприклад, англійська та французька філологія, російська та англійська тощо [5] .

Іноземна мова у ЗВО викладається лише у перші роки навчання й передбачає вдосконалення загальних навичок усного та писемного мовлення, перекладу, але не спрямована на формування професійного рівня спілкування. Кожен студент має право на вибір мови, яку він вивчатиме (зазвичай обирають ту мову, яка вивчалася у дитсадку та в школі).

Для студентів, які прибувають на навчання 3-за закордону, розроблені спеціальні програми, за якими їм дозволяється впродовж першого року навчатися англійською або російською мовами. Перевагою цих програм є їх ефективність, а недоліком - те, що лише окремі заклади вищої освіти впроваджують таку форму навчання [2].

Загалом питання інтеграції іншомовної освіти у ЗВО Литви недостатньо висвітлене, адже власна мовна політика кожного закладу не дозволяє провести повноцінного аналізу, а отже, зробити узагальнюючі висновки.

Висновки. Таким чином, проаналізувавши особливості здобуття іншомовної освіти у ЗВО країн Балтії, зокрема Латвії, Литві та Естонії, можемо зробити висновок, що нормативно-правова та законодавча база кожної із них забезпечує якісне здобуття освіти її громадянами. При цьому найбільш популярними серед іноземних мов $є$ англійська та російська.

У Латвії та Естонії, завдяки ефективному впровадженню спецкурсів і факультативів іноземними мовами, викладанню вузькоспецифічних і професійно спрямованих дисциплін кількома іноземними мовами, відзначається високий рівень оволодіння здобувачів освіти іноземними мовами, а як наслідок - випускники цих 3ВО професійно володіють не однією, а кількома іноземними мовами. Щодо випускників 3ВО Литви, то вони здобувають навички іншомовного мовлення та вільного спілкування, однак такі навички зазвичай формуються в школі. Освоєння професійного рівня іншомовної освіти у країні $€$ необов'язковим, тобто за бажанням студента.

Подальші наші дослідження плануємо спрямувати на аналіз особливостей упровадження іноземної мови в шкільну освіту країн Балтії, а також на характеристику методів та структури викладання іноземної мови на різних етапах іiі навчання. 


\section{СПИСОК ВИКОРИСТАНОЇ ЛТТЕРАТУРИ}

1. Балабанов К. В. Основні тенденції розвитку освіти i науки у Свропейському Союзі / К. В. Балабанов. URL: www.nbuv.gov.ua/Portal/soc_gum/ Prvs/2009_3/1047.pdf (дата звернення: 09.09.2019).

2. Кушнарьова М. Б. Теоретичні засади багатокультурності та світовий досвід / М. Б. Кушнарьова, O. А. Грищенко. URL: http://www.culturalstudies.in.ua (дата звернення: 09.09.2019).

3. Першукова О. Модернізація навчання іноземних мов у європейському освітньому просторі / О. Першукова // Порівняльно-педагогічні студії. 2009. - № 1. - C. 93-104.

4. Сисоєва С. О. Освітні системи країн Свропейського Союзу: загальна характеристика : навч. посіб. / С. О. Сисоєва, Т. Є. Кристопчук. - Рівне : Овід, 2012. $352 \mathrm{c}$.

5. Системи освіти Свропи. URL: http://translate.

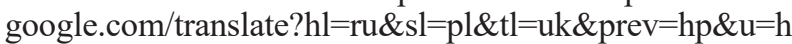
ttp://www.eurydice.org.pl/ (дата звернення: 12.09.2019).

6. Тадеєва М. І. Концептуальні засади розвитку іншомовної освіти в європейських країнах / М. I. Тадеєва // Наукові записки [Національного університету
«Острозькаакадемія»].-2012.-Вип. 25.-С.237-240.(Серія «Філологічна»).

7. Талалай Ю. Модернізація навчання іноземних мов у старших школах країн Центральної Свропи в умовах мультилінгвізму : автореф. дис. на здобуття наук. ступеня канд. пед. наук : спец. 13.00.01 / Талалай Юлія Олегівна ; Дрогоб. держ. пед. ун-т ім. Івана Франка. - Дрогобич, 2017. - 20 c. URL: http://dspu. edu.ua/wp-content/uploads/2015/09/aref-talalaj.pdf (дата звернення: 12.09.2019).

8. Хоуп М. Багатомовна Європа: тенденції у політиці та практиці мультилінгвізму у Європі / М. Хоуп. Київ : Ленвіт, 2012. - 168 с.

9. Europeans' language skills on the rise. URL: http:// www.euractiv.com /en/culture/europeans-languageskills-rise/article-152828 (дата звернення: 17.09.2019).

10. Lietuvos ekonomikos perspektyvos. DnB NORD bankas, 2009, 2. LR Visuomenès informavimo jstatymas, $1996 \mathrm{~m}$. liepos

11. Living in Lithuania. URL: http://www.studyinlithuania.1t/en/living_in_lithuania/cultureandclimate/ lithuanians (дата звернення: 15.09.2019).

Дата надходження до редакиії: 08.10.2019 р. 